University of Nebraska - Lincoln

DigitalCommons@University of Nebraska - Lincoln

2011

\title{
A high-resolution, multi-channel, over-sea-ice seismic reflection survey over the Mackay Sea Valley, Granite Harbor, Antarctica
}

B. P. Williams

Montana Tech of the University of Montana

M. A. Speece

Montana Tech of the University of Montana, MSpeece@mtech.edu

R. D. Powell

Northern Illinois University, ross@geol.niu.edu

Follow this and additional works at: https://digitalcommons.unl.edu/andrillaffiliates

Part of the Environmental Indicators and Impact Assessment Commons

Williams, B. P.; Speece, M. A.; and Powell, R. D., "A high-resolution, multi-channel, over-sea-ice seismic reflection survey over the Mackay Sea Valley, Granite Harbor, Antarctica" (2011). Related Publications from ANDRILL Affiliates. 23.

https://digitalcommons.unl.edu/andrillaffiliates/23

This Article is brought to you for free and open access by the Antarctic Drilling Program at DigitalCommons@University of Nebraska - Lincoln. It has been accepted for inclusion in Related Publications from ANDRILL Affiliates by an authorized administrator of DigitalCommons@University of Nebraska - Lincoln. 
Published in Marine Geophysical Research 32 (2011), pp. 383-395; doi: 10.1007/s11001-011-9115-3

Copyright (C) 2011 Springer Science+Business Media B.V. Used by permission.

Submitted September 8, 2010; accepted January 6, 2011; published online January 20, 2011.

\title{
A high-resolution, multi-channel, over-sea-ice seismic reflection survey over the Mackay Sea Valley, Granite Harbor, Antarctica
}

\author{
B. P. Williams, ${ }^{1}$ M. A. Speece, ${ }^{1}$ and R. D. Powell ${ }^{2}$ \\ 1. Geophysical Engineering Department, Montana Tech, 1300 West Park Street, Butte, MT 59701, USA \\ 2. Department of Geology and Environmental Geosciences, Northern Illinois University, DeKalb, IL 60115, USA \\ Corresponding author - M. A. Speece, email mspeece@mtech.edu
}

\begin{abstract}
In the austral summer of 2007, $20.5 \mathrm{~km}$ of high-resolution over-sea-ice seismic reflection data were collected in the Granite Harbor region of southern McMurdo Sound over the Mackay Sea Valley. The goal of the survey was to image thin pelagic sediment deposited in the Mackay Sea Valley after the Last Glacial Maximum. A generator-injector air gun was lowered beneath the sea ice through holes drilled by an auger drill system. The recording system was a 60 channel snow streamer with vertically oriented gimbaled geophones spaced $25 \mathrm{~m}$ apart. Unique problems in the over-sea-ice seismic reflection survey - noise from the ice column flexing and timing delays caused by trapped air at previous shot points - were overcome to improve the quality of the seismic data. The Mackay Sea Valley survey produced seismic data with a vertical resolution of $6.3 \mathrm{~m}$. The processed seismic data show pelagic sediment thickness of up to $50 \mathrm{~m}$ within the Mackay Sea Valley with some locations showing possible older sediments beneath the pelagic sediment layer.
\end{abstract}

Keywords: Antarctic, high-resolution, over-sea-ice, reflection, seismic

\section{Introduction}

Marine seismic reflection data acquisition projects that target recent sediment deposits often collect seismic data with towed high-frequency sources (Rebesco et al. 1998; Shipp et al. 1999). In polar regions, the timetable for acquisition with a research vessel depends upon the sea-ice conditions. Some polar regions expe- rience multi-year periods in which the sea ice does not break out, making conventional marine seismic surveys impossible.

Pioneers of over-sea-ice seismic methods have struggled with data quality, mainly due to poor source coupling, noise from sea-ice flexing, and bubble-pulse noise from expansion and collapse of gas in the water column (Proubasta 1985; Davy and Alder 1989; Horgan and Bannister 2004). Proubasta (1985) performed a seismic survey on both land and sea ice with a vibrator source in the Beaufort Sea and observed a flexural wave that travelled within the ice pack. Horgan and Bannister (2004) found that explosives within the sea-ice column exhibit poor source coupling. Davy and Alder (1989) performed an over-sea-ice reflection survey in the Ross Sea, Antarctica, with two different air-gun sources below the sea ice. They found that the air guns did not perform properly due to ice accumulation in the chambers. More recently, Betterly et al. (2007) successfully imaged $950 \mathrm{~m}$ thick Miocene sediment in Southern McMurdo Sound (SMS), Antarctica, with a Generator-Injector (GI) air gun as the source. The GI air gun solved the bubblepulse noise problem found in previous over-sea-ice surveys. The SMS seismic survey used a heated seismic-acquisition sled which housed the air-gun source and the data recording equipment. The $1,720 \mathrm{~cm}^{3}\left(105 \mathrm{in}^{3}\right) \mathrm{GI}$ air gun was operated in harmonic mode at a pressure of $3.4 \times 10^{6} \mathrm{~Pa}(500 \mathrm{psi})$. The GI air-gun configuration was designed for high energy output to increase depth 
of penetration. Betterly et al. (2007) were able to filter the ice flexural noise in the frequency-wave-number (FK) domain. Piston core analysis, ocean-circulation modeling, biogenic studies, and previous high-resolution seismic surveys in McMurdo Sound suggest that the Mackay Sea Valley (MSV) sediment might contain a detailed, high-resolution Holocene climate record for the Ross Sea (Powell 2001). Leventer et al. (1993) analyzed diatom assemblages in a core collected in Granite Harbor and found influences of the Medieval Warm Period and the Little Ice Age on long-term change in diatom assemblages. Piston cores (PC) collected during Nathaniel B. Palmer 1995 cruise (NBP95-01) NBP95-01-PC26 and NBP95-01-PC29 recovered 892 and $870 \mathrm{~cm}$, respectively, of mid-Holocene aged, highly diatomaceous sediment from the MSV (Curren 1995). Previous high-resolution seismic surveys conducted in the region were performed from research vessels towing a hydrophone. The NBP 95-01 survey used a high-frequency chirp source and found up to $90 \mathrm{~m}$ of unconsolidated sediment above an unconformity in the MSV (Domack et al. 1999). An unpublished 2000 survey by Pyne and Henrys, conducted in Granite Harbor, used a $3.5 \mathrm{kHz}$ sparker as a seismic source and was also able to image pelagic sediment. Both of these surveys identified sediment on top of the basement in the MSV; however, they did not fully establish the areal extent of these sediments because of limited profile coverage.

Our ultimate scientific goal is to recover a high-resolution Holocene climate record from the MSV. The sediments that have been identified by earlier surveys might provide that record through scientific drilling. The nearly constant state of sea ice in Granite Harbor has prevented additional conventional open-water high-resolution seismic surveys to improve seismic data areal coverage of the MSV to better define potential drilling targets. The recent successful development of over-sea-ice seismic surveying methods (Betterly et al. 2007) created the possibility of surveying in Granite Harbor while the harbor is covered with sea-ice (Figure 1). In the austral summer of 2007, $20.5 \mathrm{~km}$ of highresolution over-sea-ice seismic reflection data (MSV-07) were collected in the Granite Harbor region of southern McMurdo Sound, Antarctica (Figure 2). The goal of this survey was to image recent pelagic sediment deposited in the MSV after the Mackay Glacier retreated at the end of the Last Glacial Maximum. This paper reports on the successful use of over-sea-ice techniques to image thin, low-density sedimentary layers on the sea floor.

\section{Site geology}

The morphology of the MSV was glacially and tectonically driven (Hamilton et al. 1998, 2001).The 1,000 m deep MSV was scoured by the previous expansion of the

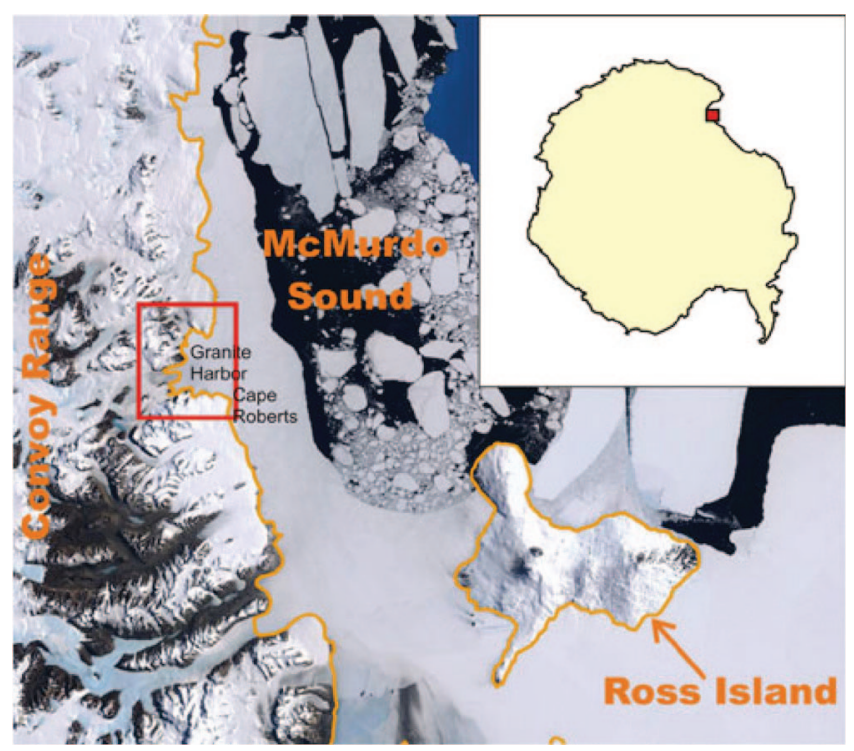

Figure 1. Satellite image of southern McMurdo Sound, Ross Sea, with the shoreline outlined in orange. The Convoy Range of the Transantarctic Mountains and Ross Island are labeled. The red square shows the survey area (Granite Harbor).

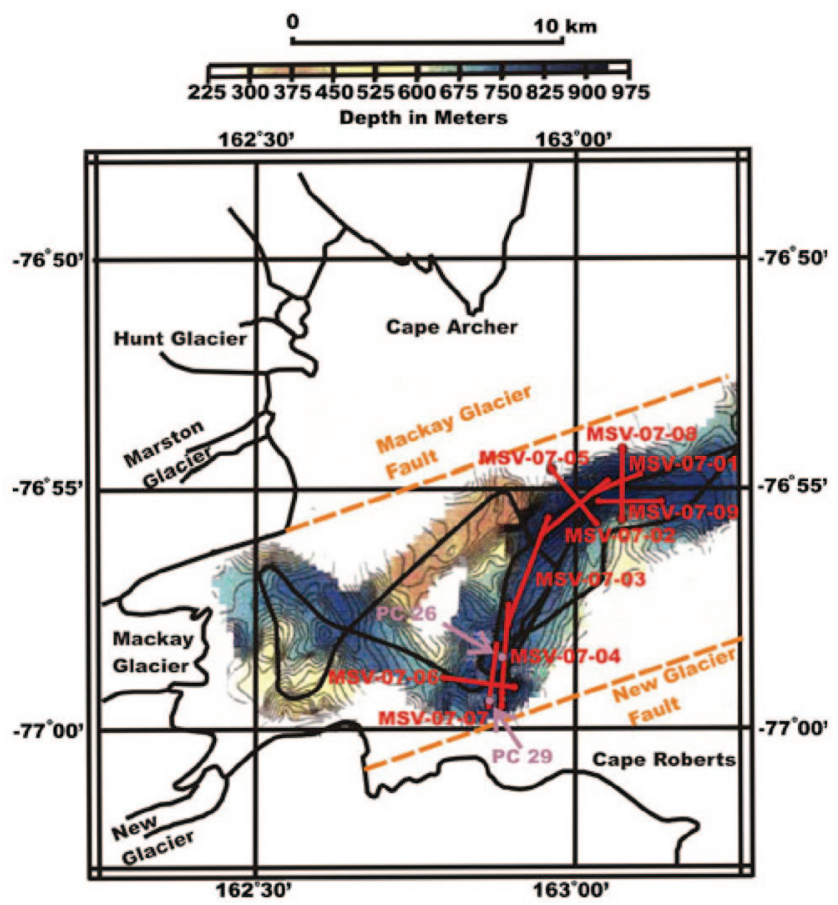

Figure 2. Location of Granite Harbor and the MSV. The nine red lines show the MSV-07 seismic survey lines. Major westeast trending faults are shown in orange. Bathymetry of MSV is in color with the key shown at the top of the figure. The locations of the piston cores sites, PC 26 and PC 29, are shown in purple and the bathymetry track lines from NBP95-01 are in black (modified after Powell 2001).

Mackay Glacier and is located in Granite Harbor on the southern coast of Victoria Land (Figure 1). Granite Harbor is bordered to the south by Cape Roberts Rift Basin and the Transantarctic Mountains to the west. Trending 
WSW-ENE, the MSV truncates the Cape Roberts Rift Basin (Figure 2). Hamilton et al. $(1998,2001)$ projected the ENE-trending New Glacier Fault parallel to MSV's southern extent which suggests that this fault controlled the valley morphology. Extensive study of the region indicates a Late Ordovician intrusive granite basement for the Convoy range, benches, and the coastal piedmonts (Gunn and Warren 1962; Burgess et al. 1981; Pocknall et al. 1994; Sugden and Denton 2004).

The Mackay Glacier is an outlet of the East Antarctica Ice Sheet that flows through the Convoy range of the Transantarctic Mountains. Episodic glacial retreat and advances have transpired in the Granite Harbor area, the last advance occurring 18-21 k.a. which carved the MSV (Powell 2001). The present day Mackay Glacier terminates as a floating glacier-tongue in Granite Harbor.

McMurdo Dry Valley sediment fill and offshore drilling indicate that the MSV was formed as early as the Miocene (e.g. McGinnis 1981; Hambrey and Barrett 1993; Powell et al. 1998; Cape Roberts Science Team 1998, 1999, 2000; Powell 2001). However, evidence of reworked Pliocene-age microfossils in the CRP-1 core located on the Cape Roberts Ridge indicate possible glacial grounding as early as the Pliocene (Cape Roberts Science Team 1998). Domack et al. (1999) ${ }^{14} \mathrm{C}$-dated the diatom rich sediment in the $8 \mathrm{~m}$ piston cores NBP9501-PC26 and NBP95-01-PC29 to 6.5 k.a. This date for the top $8 \mathrm{~m}$ of sediment postdates the time postulated for the Antarctic Ice Sheet retreat past the MSV between about 7.6 and 6.8 k.a. (Licht et al. 1996; Conway et al. 1999; Domack et al. 1999; Hall and Denton 1999; Powell 2001).

Microstratigraphic techniques have been applied to the cores collected in the region during the NBP 9401 and NBP 95-01 cruises. Domack et al. (1999) identified four primary sedimentary facies associated with the most recent glacial expansion and retreat in the Ross Sea: a basal diamicton unit, a sand unit with mud and pelletized gravel, a mud unit, and a diatomaceous mud and ooze unit. The basal diamicton is correlated with seismic facies 2, 3, and 4a of Shipp et al. (1999) that were identified on the central Ross Sea continental shelf. Because its $10-50 \mathrm{~cm}$ thickness is too thin to resolve seismically, the sand unit with mud and pelletized gravel is incorporated into seismic facies 2 and 3 of Shipp et al. (1999), and is interpreted as having been deposited close to the ice-shelf grounding line. A several-meterthick mud unit corresponds to Shipp et al.'s (1999) seismic facies 5. The several-meter-thick mud facies was deposited sub-ice distal to the grounding line. The diatomaceous mud and ooze unit indicates an open marine environment and is associated with seismic facies 1 of Shipp et al. (1999).

The NBP 95-01 seismic survey imaged $90 \mathrm{~m}$ of Holocene sediment above an unconformity with gently folded rock below the unconformity. Domack et al.
(1999) suggest that the gently folded rock was not granitic basement. Depending on the age at which the unconformity was created, the gently folded rock could be old interglacial sediment deposited in late Neogene, Pleistocene, or Pliocene. With this knowledge, an earth model can be developed for the MSV. This model has a thin sequence of pelagic sediment resting above a granitic basement. However, remnants of diamicton from previous glaciations or overridden interglacial sediments, corresponding to the gently folded rock of seen in the NB 95-01 survey, could remain in the MSV and should be considered.

\section{Equipment and procedure}

Similar to the SMS survey (Betterly et al. 2007), the Mackay Sea Valley 2007 (MSV-07) survey used a Generator-Injector (GI) air-gun source housed in a heated sled that pulled a snow streamer comprising a 60 gimbaled geophone array. The shot move-up for the MSV survey was reduced to $50 \mathrm{~m}$ to increase the nominal fold of the MSV-07 over the SMS survey (Table 1).

A GI air gun was used as the seismic source to mitigate bubble-pulse noise. GI air guns have two air chambers: the generator chamber and the injector chamber.

Table 1. Seismic acquisition parameters

\begin{tabular}{ll}
\hline Source type & Seismic systems 3,440 $\mathrm{cm}^{3}\left(210 \mathrm{in}^{3}\right)$ \\
& Generator-injector air gun \\
Source mode & True GI (MSV-07-01 to MSV-07-04) \\
& Generator volume: $737 \mathrm{~cm}^{3}\left(45 \mathrm{in}^{3}\right)$ \\
& Injector volume: $1,720 \mathrm{~cm}^{3}\left(105 \mathrm{in}^{3}\right)$ \\
& Harmonic (MSV-07-05 to \\
& MSV-07-09) \\
& Generator volume: $409 \mathrm{~cm}^{3}\left(25 \mathrm{in}^{3}\right)$ \\
& Injector volume: $409 \mathrm{~cm}^{3}\left(25 \mathrm{in}^{3}\right)$ \\
Recording system & Geometrics geode \\
Source offset & $2 \mathrm{~m}$ perpendicular to survey line \\
Shot depth & $5 \mathrm{~m}$ for the first $13 \mathrm{shots} \mathrm{in}$ \\
& $\quad$ MSV-07-01 \\
Air-gun pressure & $1.4 \times 10^{7}$ Pa (2,000 psi) \\
Stacks & Minimum of four \\
Receiver interval & $25 \mathrm{~m}$ \\
Shot interval & $50 \mathrm{~m}$ \\
Shot-receiver near offset & $25 \mathrm{~m}$ \\
Shot-receiver far offset & $1,500 \mathrm{~m}$ \\
Nominal fold & 15 \\
Live channels & 60 \\
Survey geometry & Off end \\
Sampling period & $0.5 \mathrm{~ms}$ \\
Record length & $3 \mathrm{~s}$ \\
\hline & \\
& \\
&
\end{tabular}


Figure 3. a) Picture of the seismic data acquisition equipment of the MSV seismic survey. b) Diagram of the field layout of the MSV seismic survey. Shot spacing was $50 \mathrm{~m}$ and receiver spacing was $25 \mathrm{~m}$ (modified after Speece et al. 2009). (a)

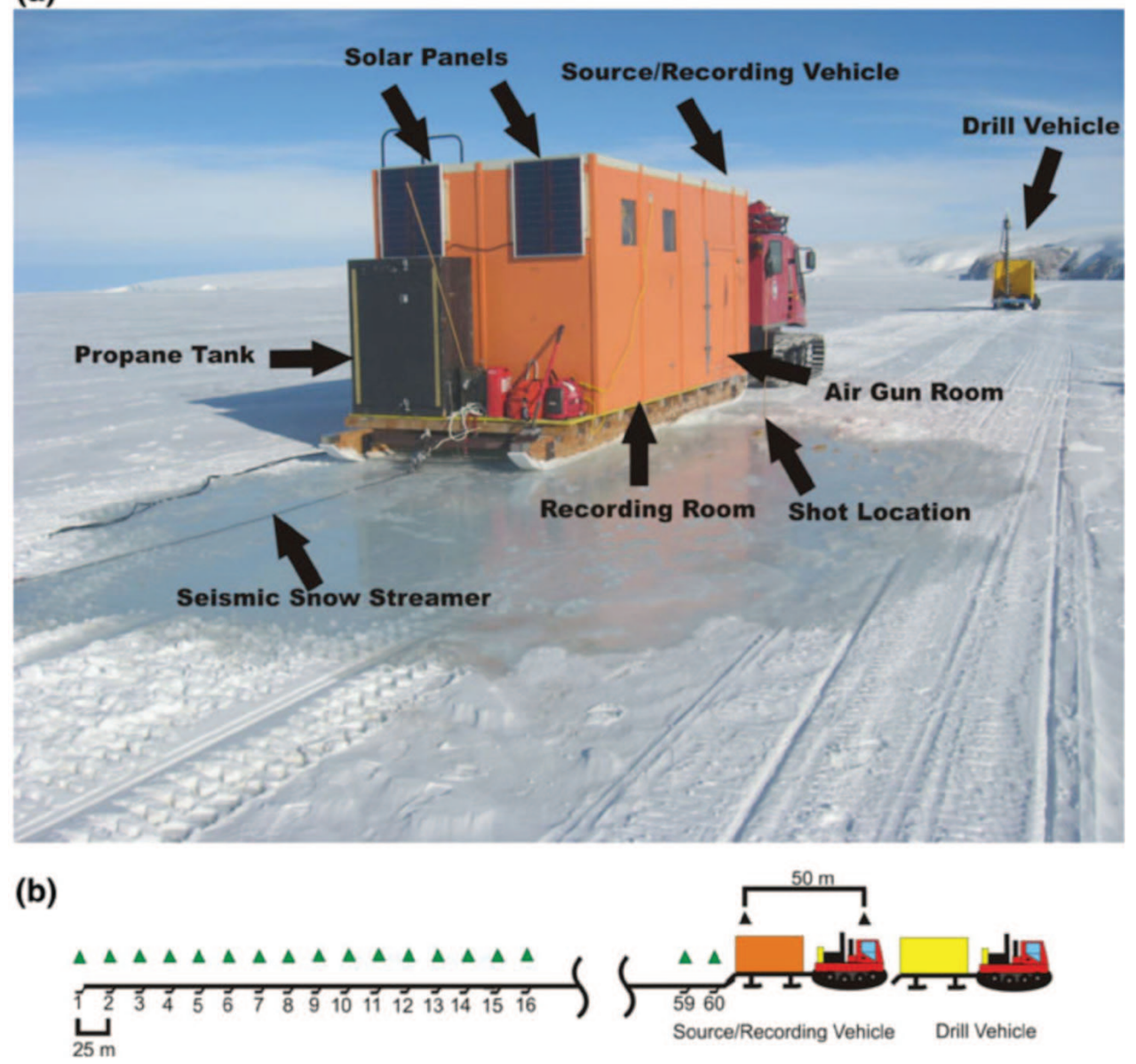

The generator chamber is fired first, and after a time delay, the injector is fired inside the first bubble to suppress bubble-pulse noise. The GI air gun has different chamber configurations to achieve bubble pulse cancellation (Table 1). The GI air gun can be configured in two modes: true GI and harmonic. True-GI mode multiplies the primary-to-bubble ratio by nearly seven resulting in an almost total suppression of the bubble pulse while the harmonic mode multiplies the primary-to-bubble ratio by four compared to an ordinary air gun (Sercel 2006). Although true-GI mode is more ideal for suppressing the bubble pulse, harmonic mode is able to suppress the bubble pulse while allowing for a lower volume of air than the true-GI mode. Because we were using a relatively small air compressor, to conserve air volume and thereby decrease data acquisition time, we decided to switch to harmonic mode part way through the survey. Lines MSV-07-01 to MSV-07-04 were collected with a GI gun in true-GI mode. Lines MSV-07-05 to MSV-0709 were collected with a GI gun in the smallest volume harmonic mode configuration. The GI air-gun air supply was provided by a Bauer dive compressor that filled a four air cylinder array. The air compressor was rated at $1.4 \times 10^{5} \mathrm{~cm}^{3}$ per minute at $2.4 \times 10^{7} \mathrm{~Pa}(3,500 \mathrm{psi})$. An air pressure gauge was used to monitor a constant air- gun-operating pressure of $1.4 \times 10^{7} \mathrm{~Pa}(2,000 \mathrm{psi})$.

The snow streamer was divided into five sections, each of which has 12 channel takeouts. The channel takeouts are $25 \mathrm{~m}$ apart (Figure 3). The channel outputs were fed into the seismic sled and connected to a recording system housed in a room separate from the airgun room. Attached to the $1,475 \mathrm{~m}$ long snow streamer were 60 vertically oriented, $30 \mathrm{~Hz}$, gimbaled geophones. These geophones are $360^{\circ}$ roll gimbaled and have a $180^{\circ}$ pitch tolerance. At each snow streamer section connection, we used a plastic sled to reduce friction between the cable head and the snow. The streamer has an internal Kevlar strength member designed to withstand a load of $13,000 \mathrm{~N}(2,900 \mathrm{lb})$. The strength member is attached to the seismic sled via a braided steel cable connected to a load cell.

The shot locations were surveyed with a handheld monocular with crosshairs and a measuring chain. The monocular was used to ensure that the line was straight and the chain was used to measure the 50-m distance between shot locations. Holes would later be drilled at these shot locations through the 2-m thick sea ice with a drill rig consisting of a Pisten Bully pulling a hydraulically powered auger drill system on a Hagglund sled platform (Figure 3). 


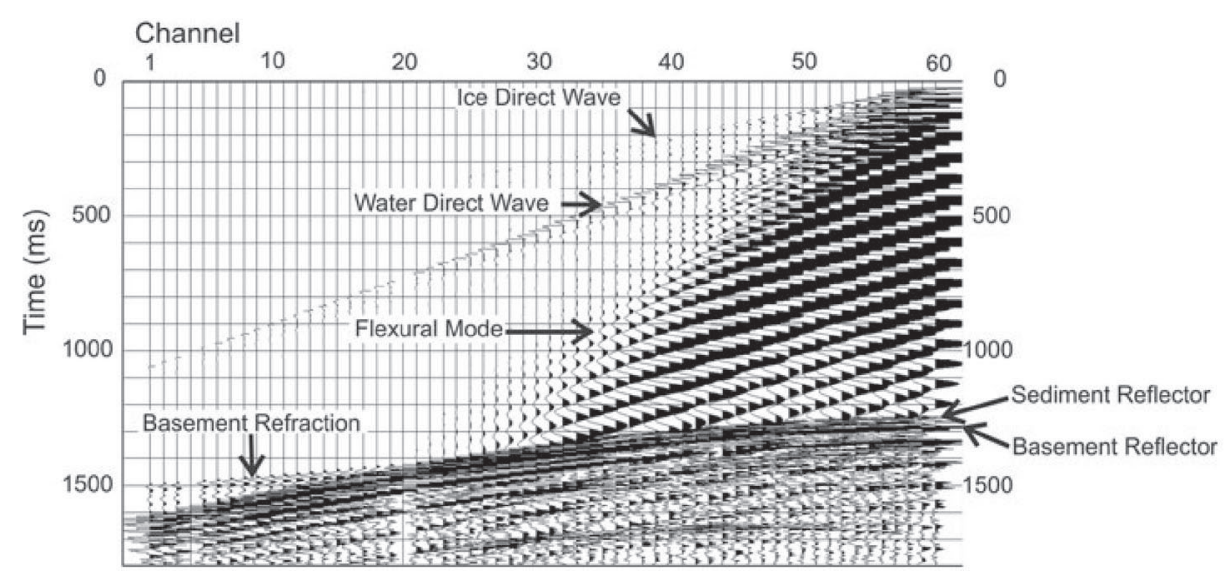

Figure 4. Raw shot record with seismic events labeled.

During shot move-ups, a field worker would monitor the load cell to ensure that the force on the strength member did not exceed the set load tolerance of $6,700 \mathrm{~N}$ $(1,500 \mathrm{lb})$. Cable noise was reduced by releasing tension in the tow cable after the shot move-up. This was accomplished by pulling the seismic data recording sled slightly past the drilled hole and then backing up until the air gun was in line with the hole.

Once the gun was in line with the shot hole, the gun was lowered to a depth of $5 \mathrm{~m}$ from the ice surface to avoid platelet ice interfering with air chamber sealing. To reduce the ice flexural-mode noise in the data, the air-gun depth was increased to $8 \mathrm{~m}$ after the 13th shot location on line MSV-07-01. After four quality shots were recorded at a shot location, the gun was stored back inside the heated gun room.

\section{Processing}

A raw shot record acquired along MSV-07-02 shows the direct wave from the water-ice boundary, high amplitude, linear flexural-mode noise, low amplitude sediment reflectors, the high amplitude basement reflector, and basement ringing (Figure 4). The shot also shows the basement refraction.

The seismic data were processed through post-stack depth migration (Table 2). Noisy traces were killed, poor shot records removed, and timing errors were corrected prior to stacking individual shots at each shot location. Timing errors were generated by improper synchronization between the air gun and the acquisition software, which caused the air gun to fire before the acquisition software started to record (Daniel Hobson, RTS Inc., personal communication, 2010). In conventional marine seismic surveys, the air guns are calibrated after several test shots to ensure proper air gun and acquisition software synchronization. The air system used in the MSV survey was not able to support the extra air needed for calibrating shots at each shot location and we chose to record all shots and correct for timing errors due to airgun software synchronization later in processing. To accomplish this, a theoretical first break time for the ice direct wave was calculated for both shot depths of 5 and $8 \mathrm{~m}$ respectively. The first break time was calculated using ice velocity of $3,000 \mathrm{~m} / \mathrm{s}$, water velocity of $1,440 \mathrm{~m} / \mathrm{s}$, and ray paths estimated using Snell's Law. The first break for each shot record was corrected to the

Table 2. Processing flow

Trace editing

Source static corrections

Source stack (vertically summed)

Phase reversal

Shot statics

Trace balancing

Spherical divergence correction

F-K filtering

Sort to CDP

Velocity analysis

Normal-moveout-correction

Brute stack

Predictive deconvolution

Bandpass filter

Residual statics

Velocity function update

Dip-move-out correction

Velocity function update

Normal-moveout-correction

Final CDP time stack

FX deconvolution

Post-stack kirchhoff depth migration

Top mute

Final migrated stack 


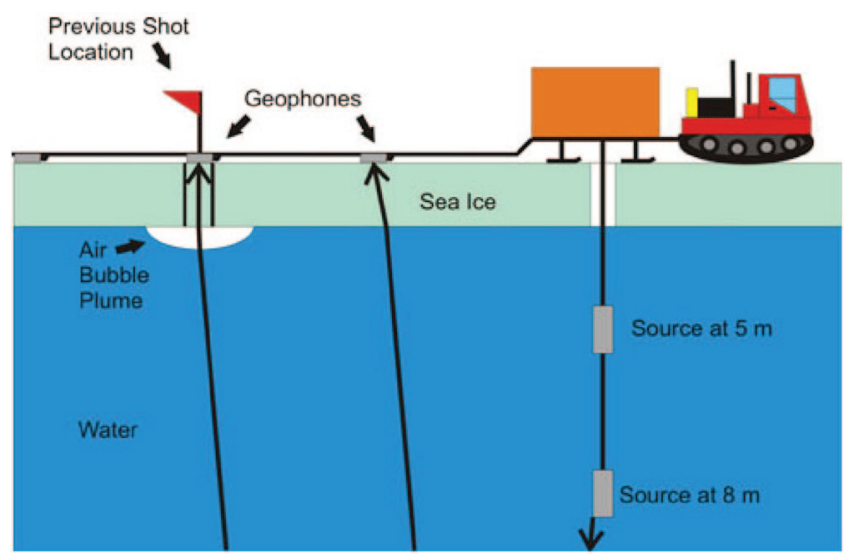

Figure 5. Illustration depicting the air bubble plumes trapped beneath the sea ice at previous shot locations and reflected wave paths.
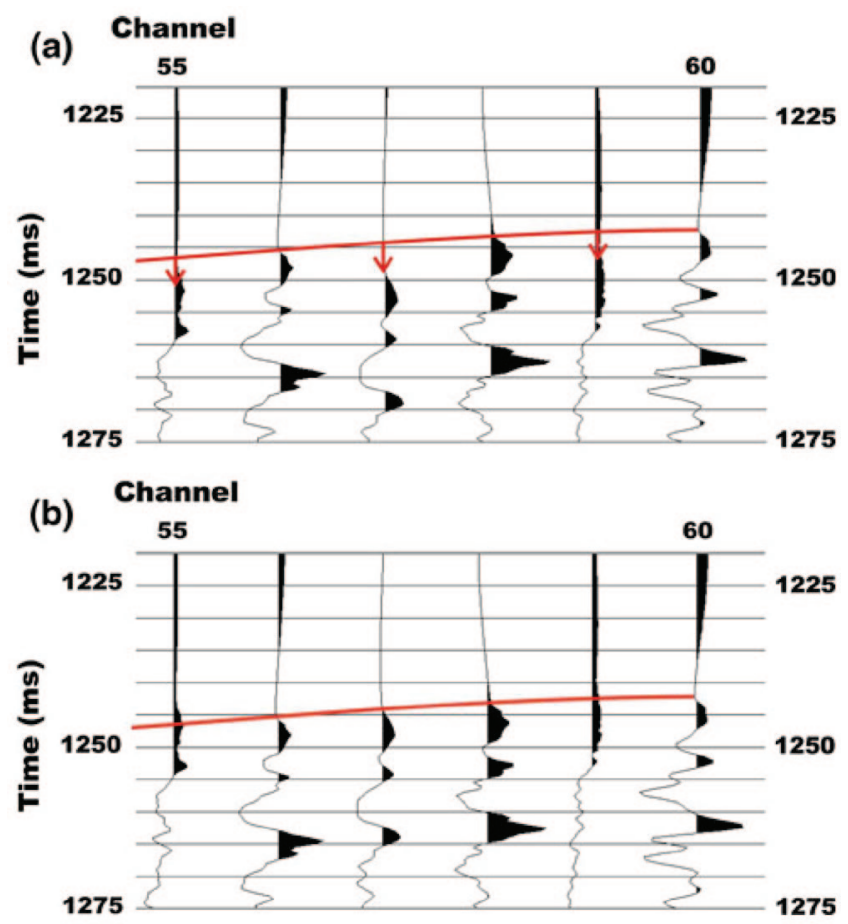

Figure 6. a) Shot gather showing timing delays caused by trapped air beneath the ice. b) Same shot record after a static correction of $5 \mathrm{~ms}$ was applied to the delayed traces.

corresponding calculated first break time to correct for timing errors so that shot records had a consistent time zero. Since the gun depth was increased from 5 to $8 \mathrm{~m}$ during MSV-07-01 (Figure 5), a static correction was applied to the first 13 shot records to achieve the same datum. After the shot records were edited, the shot records at each station were stacked (vertically summed) to reduce wind noise and improve the overall signalto-noise ratio. Phase reversal was done for all data to match the convention of positive amplitude for a velocity contrast increase.
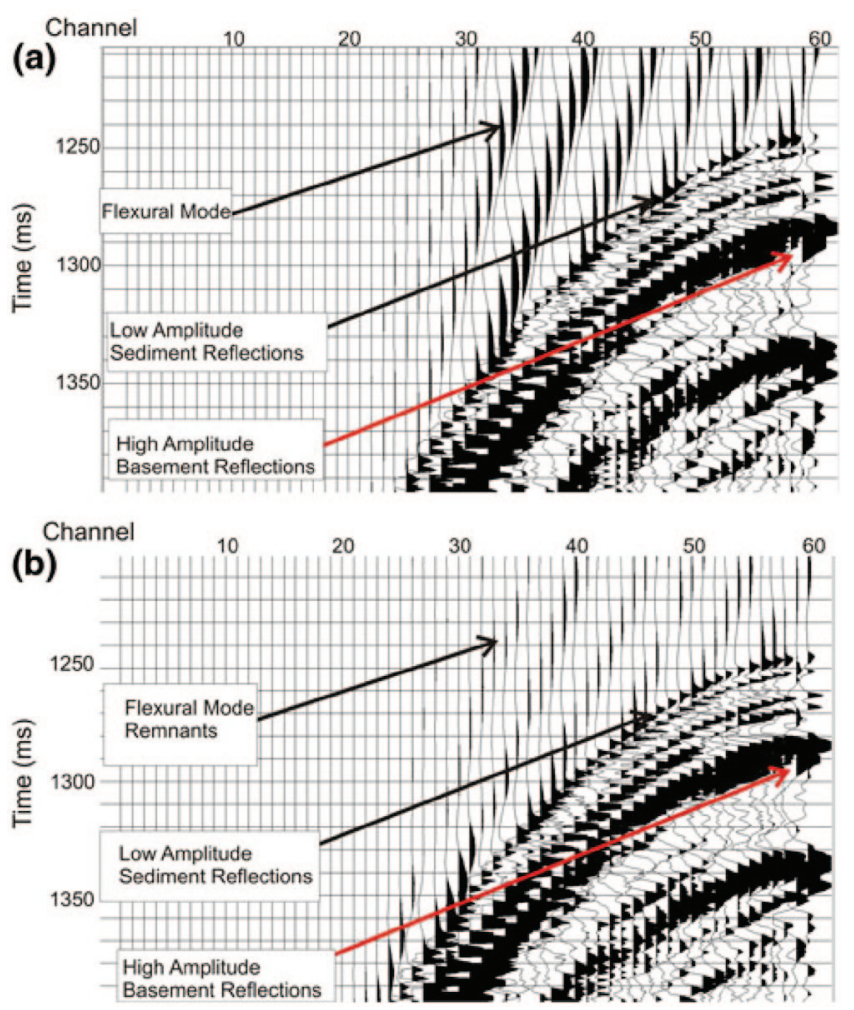

Figure 7. a) Shot gather showing the dominant noise in the data from ice flexing. b) Same shot gather after a polygon filter was applied in the F-K domain which reduced the flexuralmode noise.

A close look at the reflections indicates a timing delay inherent in this over-sea-ice seismic method (Figure 6). Static errors were detected on traces that occupied previous shot locations. These static errors were caused by air bubble plumes trapped beneath the ice (Sunwall et al. 2010). These bubbles are remnants of the released air from the GI air gun from when the source occupied the station (Figure 5). A time static correction of 2-5 ms was applied to the traces that occupied previous shot locations. Hand statics were used because the timing delays were easily observable at predictable trace spacing. Residual statics were done later to further fix any remnant timing problems.

When seismic waves traveled through the air/water interface, a short-period multiple was created that broadened the wavelets. Short-period deconvolution helped compress the wavelet.

The dominant noise in the data is the ice flexural mode (Ewing and Crary 1934; Lewis 1973; Shei et al. 1983; Lansley et al. 1984; Proubasta 1985; McConnell et al. 1986; Barton et al. 1986; Beresford-Smith and Rango 1988; Barr et al. 1993; Del Molino et al. 2008). This noise is linear, has a frequency range of $10-20 \mathrm{~Hz}$, and is high-amplitude. It is easily distinguished from other events in the frequencywavenumber (F-K) domain. The flexural mode was removed with a polygon reject filter in the $\mathrm{F}-\mathrm{K}$ domain (Figure 7). 


\section{Results}

The dominant wavelength for the depth-migrated soft sediment layers is $25 \mathrm{~m}$ so the vertical resolution for the sediment was calculated to be $6.3 \mathrm{~m}$ using the Rayleigh criterion. A horizontal resolution (first full Fresnel zone) of $212 \mathrm{~m}$ was calculated using a target depth of $900 \mathrm{~m}$ at the bottom of the Mackay Sea Valley.

The true-GI mode data and the harmonic mode data have comparable source autocorrelations and frequencies (Figure 8). A stronger flexural mode is observed in shot records collected in the true-GI mode. The larger air volumes used in this mode most likely caused the ice to flex more than for the lower volume harmonic mode (Table 1). The lower volume used in the harmonic mode also contributed to a higher frequency content compared to the true-GI mode (Figure 8). The greater injector volume in the true-GI mode did reduce bubble pulse better than the harmonic mode; however, this improvement was small.

We generated a synthetic shot gather to validate the model of a thin draping of unconsolidated sediment overlying a granite basement (Figure 9). A point source finite difference modeling program was used to generate the synthetic shot record. The finite difference modeling can produce direct waves and multiples in the synthetic shot record. We used a zero-phase Ricker wavelet with peak frequency $80 \mathrm{~Hz}$ which is comparable to the source wavelet in the MSV data (Figure 10). The source depth in the modeling was $8 \mathrm{~m}$ from the ice surface. For the modeling the 2-m-thick sea-ice a density of $900 \mathrm{~kg} / \mathrm{m}^{3}$ (Timco and Frederking 1996) and a velocity of $3,000 \mathrm{~m} / \mathrm{s}$ (found using the direct ice arrival in the shot records) were used. The water density was set to $1,000 \mathrm{~kg} / \mathrm{m}^{3}$. A velocity of $1,440 \mathrm{~m} / \mathrm{s}$ for water was calculated from the water direct arrival in the shot gathers. Diatomaceous ooze has a density range from 1,300 to $1,500 \mathrm{~kg} / \mathrm{m}^{3}$ (Kuzmin et al. 2000). The density for the uppermost pelagic sediment in the synthetic shot record was $1,300 \mathrm{~kg} / \mathrm{m}^{3}$ and the velocity was $1,500 \mathrm{~m} / \mathrm{s}$. The density and velocity values for the denser second sediment layer were $1,400 \mathrm{~kg} / \mathrm{m}^{3}$ and $1,550 \mathrm{~m} / \mathrm{s}$, respectively. For the third layer of pelagic sediment, a density of $1,500 \mathrm{~kg} / \mathrm{m}^{3}$ and a velocity of $1,600 \mathrm{~m} / \mathrm{s}$ were used. The weathered granite velocity $(4,800 \mathrm{~m} / \mathrm{s})$ was found from the granite refraction observed on the shot gathers. Density for weathered granite in the Victoria Land has a density of approximately $2,500 \mathrm{~kg} / \mathrm{m}^{3}$ (Elliott 2006). Density and velocity for the competent granite basement were $2,700 \mathrm{~kg} / \mathrm{m}^{3}$ and $5,500 \mathrm{~m} / \mathrm{s}$, respectively (Clark et al. 1966). The resulting reflection coefficient for the water-sediment interface is 0.15 and the sediment-weathered basement is 0.67. The Two-Way-Travel Time (TWTT) and the amplitude of the reflectors in the synthetic model are consistent with the raw shot records (Figure 9). The synthetic
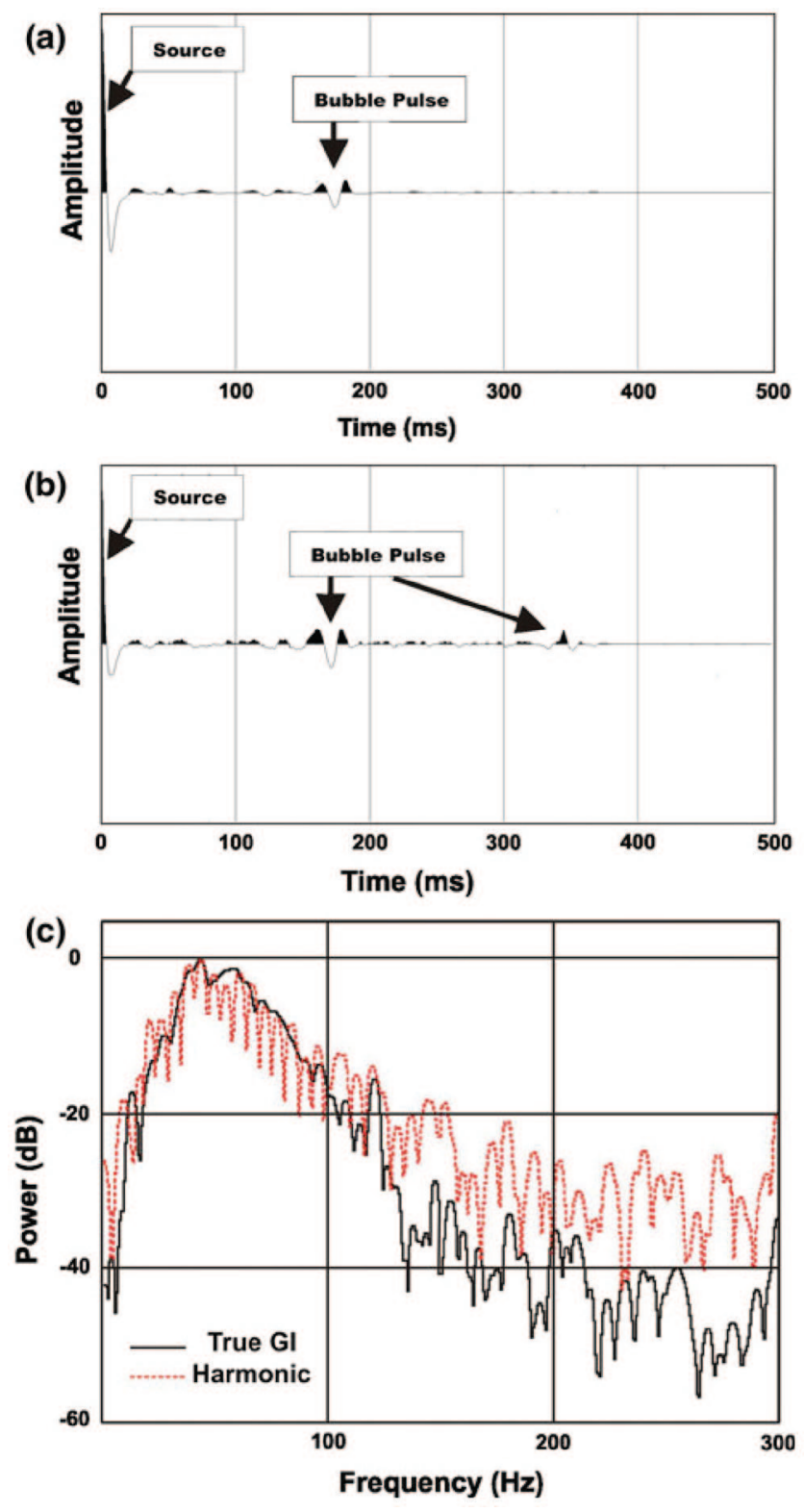

Figure 8. Typical autocorrelation of traces from shot records in the true-GI (a) and harmonic mode (b) with source wavelet and bubble pulses indicated. (c) The frequency content of the autocorrelations. Autocorrelations were done on a window above the ice flexural mode that includes the ice and water direct arrivals from both source modes. This window was chosen because other periodicities in the data such as the flexural mode masked the bubble pulse.

model demonstrates that given favorable conditions and reasonably high-frequency data we should be able to image the larger deposits of sediment.

The survey vertical resolution was not sufficient to resolve the decimeter-scale beds in the pelagic sediment (Curren 1995), but we were able to image thicker layers (Figures 11-17). Pelagic sediment drapes over the granite basement throughout MSV-07-02 with 65 ms TWTT of sediment occurring at a distance of 3,200 m (Figure 
Figure 9. Comparison of an interpreted F-K filtered shot record (a) and a generated synthetic shot record (b) with the earth model used to generate the synthetic shown to the left. The synthetic shot depth was $8 \mathrm{~m}$. The yellow line is the top of sediment and the red line represents the top of the basement. Both right hand corners of the shot records have a zoomed inset of the near-offset sediment and basement reflectors.
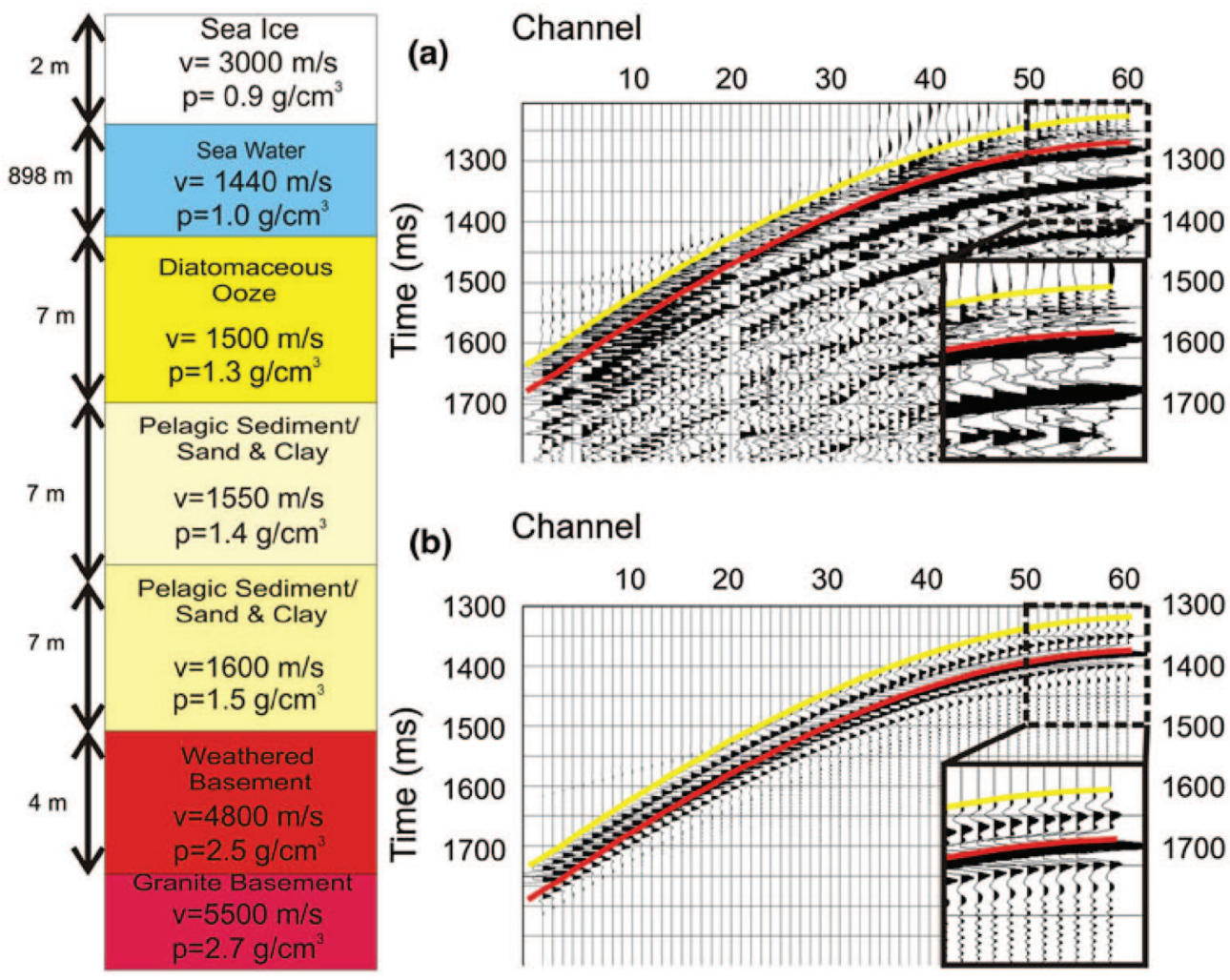

(b)

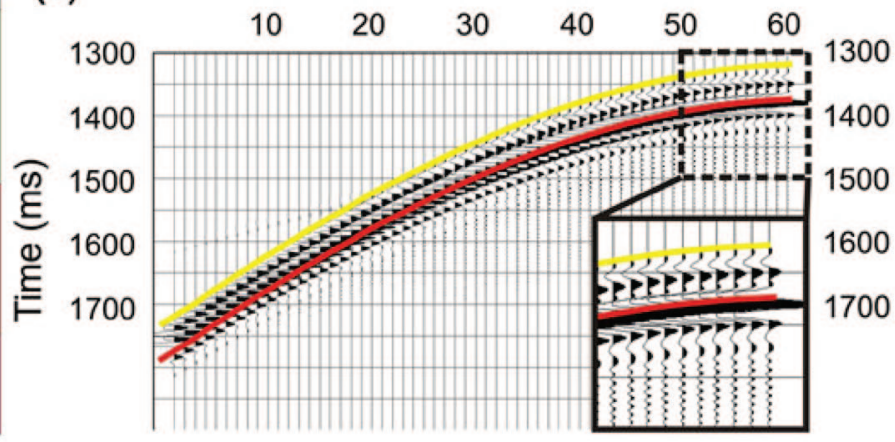

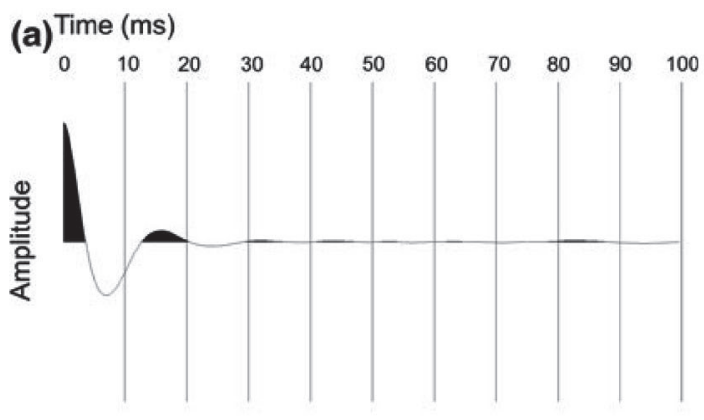

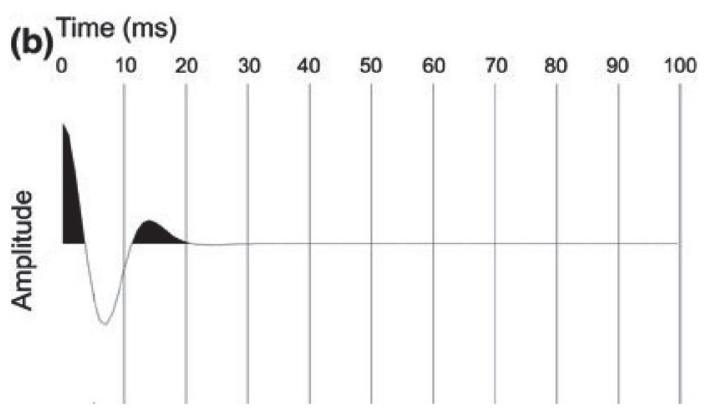

Figure 10. Comparison of typical recorded data trace autocorrelation from an F-K filtered shot record (a) and a synthetic trace autocorrelation from the synthetic shot record in Figure 9 (b). The autocorrelations show the similarity between the data source pulse and the modeled source pulse.

$11 \mathrm{a}, \mathrm{b})$ along the unmigrated time section. The corresponding depth-migrated section of MSV-07-02 shows sediment thickness up to $50 \mathrm{~m}$ (Figure 11c). In addition, a thick sediment deposit is seen beneath the northeast edge of MSV-07-03 (Figure 12). The thickest sediment accumulation occurs at the $500 \mathrm{~m}$ distance mark and is $50 \mathrm{~ms}$ TWTT thick (Figure 12a) on the time section and $40 \mathrm{~m}$ thick on the depth-migrated section (Figure 12b). MSV-07-04 shows thick sediment between 3,700 and 4,100 $\mathrm{m}$ distance marks (Figure 13a). The thickest section of the sediment occurs at the 3,900 m distance mark with $65 \mathrm{~ms}$ TWTT thickness on the time section (Figure 13a) corresponding to $50 \mathrm{~m}$ on the depth section (Figure 13b). The time section of MSV-07-05 indicates up to 40 ms TWTT of sediment between the 1,500 and 2,300 $\mathrm{m}$ distances along the profile (Figure 14a). This corresponds to up to $30 \mathrm{~m}$ of pelagic sediment on the depth-migrated section (Figure 14b). Pelagic sediment is present all along MSV-07-06 with the thickest section occurring at the 1,900 m distance mark (Figure 15a). The time section shows 50 ms TWTT (Figure 15a) corresponding to $40 \mathrm{~m}$ of sediment on the depth section at the 1,900 $\mathrm{m}$ distance mark (Figure 15b). The MSV-07-07 time section shows up to $45 \mathrm{~ms}$ TWTT of pelagic sediment being deposited in the region between the 2,200 and 3,100 m distance marks (Figure 16a). This corresponds to $35 \mathrm{~m}$ in the depth-migrated section (Figure 16b).

The top reflection represents the water-sediment boundary. The internal reflections are likely due to variations in sediment lithology. Beneath the sediment zone lies a high-amplitude reflection which is the sediment-basement interface. We used post-stack Kirchhoff depth migration to convert from time to depth. The 

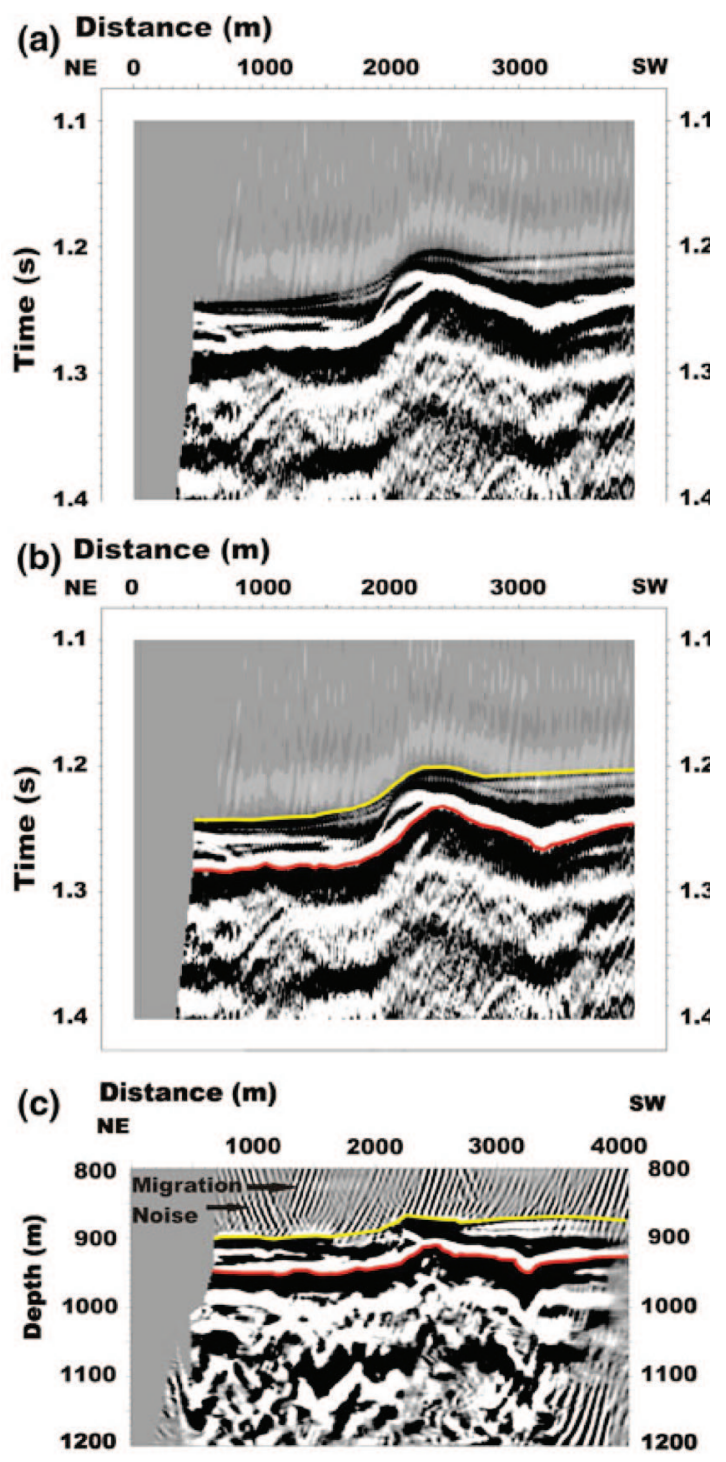

Figure 11. a) MSV-07-02 uninterpreted and unmigrated Common-MidPoint (CMP) stacked time section for reference before interpretation. b) MSV-07-02 unmigrated CMP stacked time section with interpretations. The yellow line is the interpreted top of sediment and the red line is the top of the basement. The time section shows 65 ms TWTT of sediment. c MSV-0702 depth-migrated CMP stacked section with interpretations. The depth section indicates sediment thickness of up to $50 \mathrm{~m}$. The MSV-07-02 depth-migrated section does not have a seafloor mute to demonstrate migration noise present in depthmigrated sections.

migration broadens the MSV which helps with perspective and scale during interpretation. However, migration and out-of-plane noise obscure the low amplitude sediment in lines with steeply dipping canyon walls, which complicates interpretation of the depth sections. The steep velocity gradient that exists between the sediment and granite or water and granite interfaces guarantees that migration noise will be observed above the basement in the migrated sections.
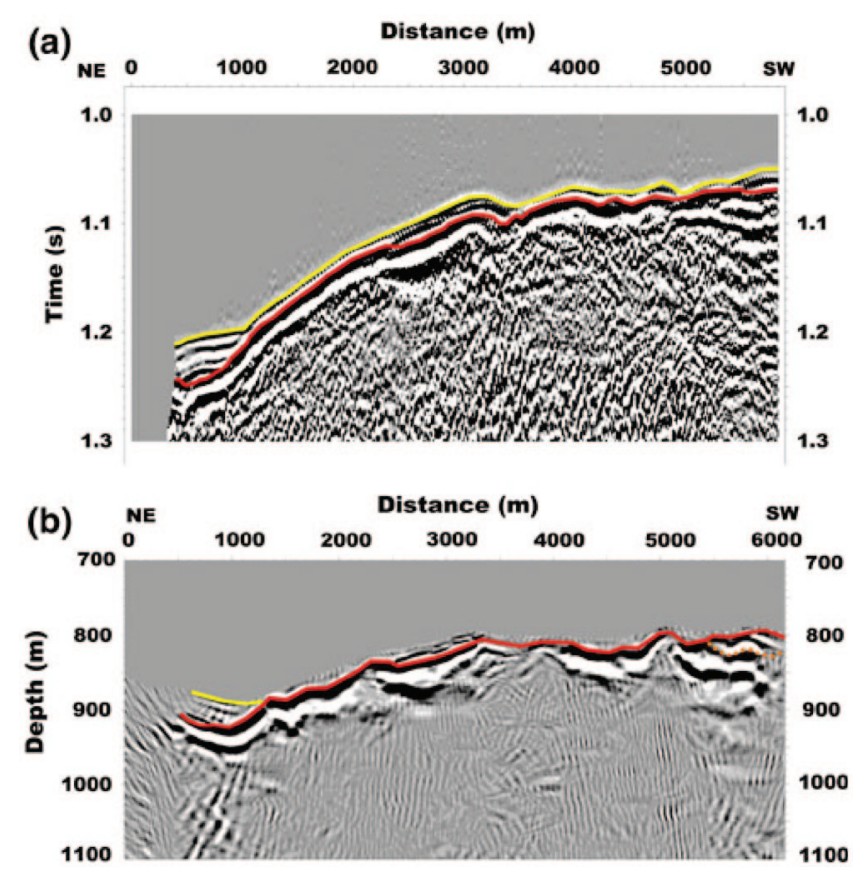

Figure 12. a) MSV-07-03 unmigrated CMP stacked time section with interpretations. The yellow line is the interpreted top of sediment and the red line is the top of the basement. The time section shows 50 ms TWTT of sediment. b) MSV-07-03 depthmigrated CMP stacked section with interpretations. The depth section indicates a maximum sediment thickness of $40 \mathrm{~m}$. The dashed orange line is an alternate interpretation of the basement reflector on the southwestern end of MSV-07-03.

The low-amplitude reflections of the sediments and the lack of reflections in the water column cannot mask the small amount of migration noise. We used an oceanbottom mute for many of the depth-migrated sections to remove the migration noise in the water column. The migration noise was in all cases more steeply dipping than the sediment reflectors and this allowed us to interpret the top of the sediments on the migrated depth sections except where the sediment was thin (Figure 11). MSV-07-01, MSV-07-08, and MSV-0709 did not show low-amplitude reflections from sediments and are not shown in this paper.

\section{Discussion}

Reflection amplitude strength guided our interpretation of the seismic sections. Low-amplitude reflections above the shallowest high-amplitude reflection are interpreted as pelagic sediment. The top of basement was interpreted as the first high-amplitude reflector. The broad wavelet that characterizes the basement reflection could be caused by a thin layer of weathered basement. This thin layer, with a thickness less than that of the vertical resolution of the data, would cause constructive interference and would be incorporated with the competent basement reflection. 


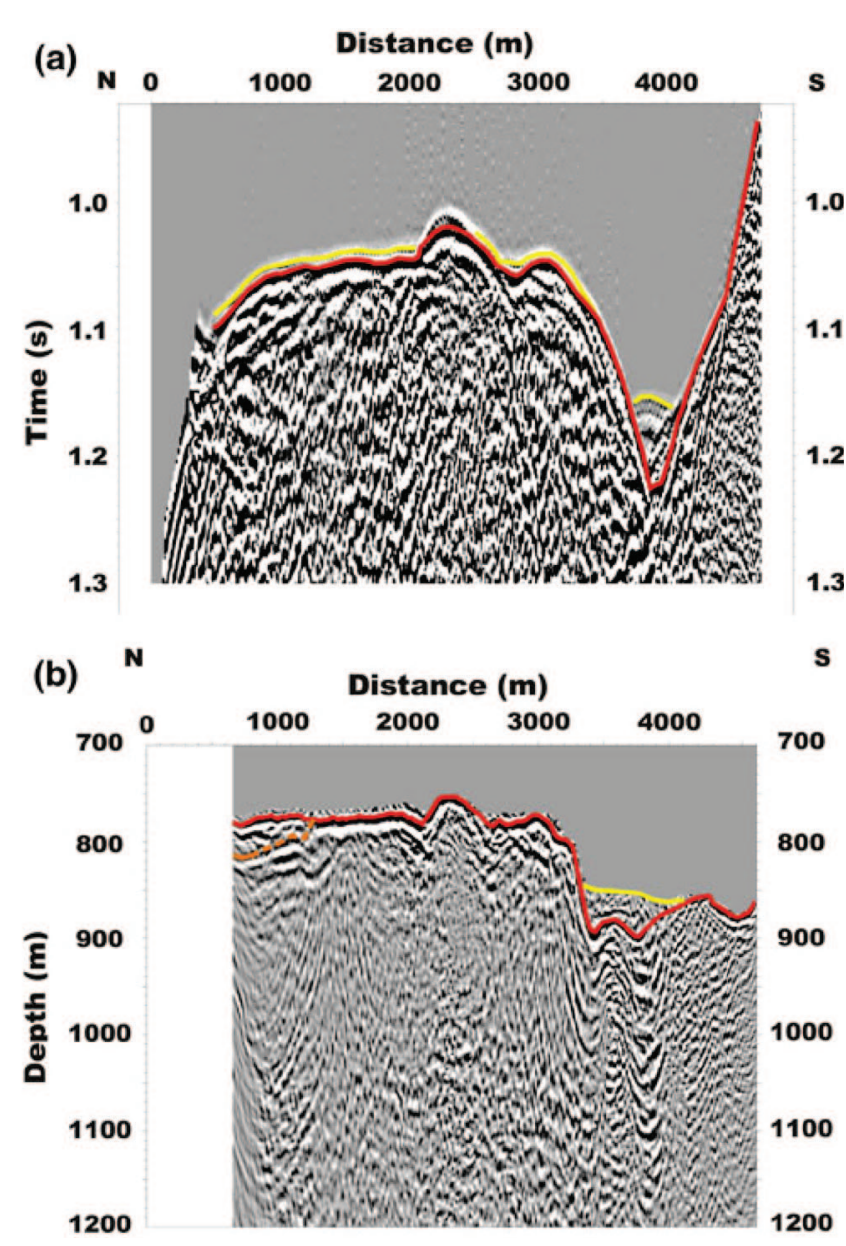

Figure 13. a) MSV-07-04 unmigrated CMP stacked time section with interpretations. The yellow line is the interpreted top of sediment and the red line is the top of the basement. The time section shows about $65 \mathrm{~ms}$ TWTT of sediment. b) MSV07-04 depth-migrated CMP stacked section with interpretations. The depth section indicates up to $50 \mathrm{~m}$ of sediment. The dashed orange line is an alternate interpretation of the basement reflector on the northern end of MSV-07-04.

Strong amplitude ringing exists beneath the interpreted bedrock reflector in the shot records. The periodicity of these peg-leg multiples is on the order of $50 \mathrm{~ms}$ TWTT which is not on the order of the bubble pulse observed in the shot autocorrelations ( 170 ms, Figure 8). Strong amplitude, low-frequency reverberations can occur in high vertical velocity gradient zones (Jensen et al. 1999; Nielsen and Thybo 2009). At nearby Cape Roberts (Figure 1), Hamilton et al. (1998) interpreted the top of basement by its strong reverberating nature at the top of an acoustically transparent interval. Deconvolution only weakened but did not remove these reverberations from the final stacked sections.

The MSV survey delineated the low-amplitude pelagic sediment within the MSV and increased the seismic data coverage in the area. The seismic data from MSV07-02, MSV-07-05, and MSV-07-07 indicate that up to

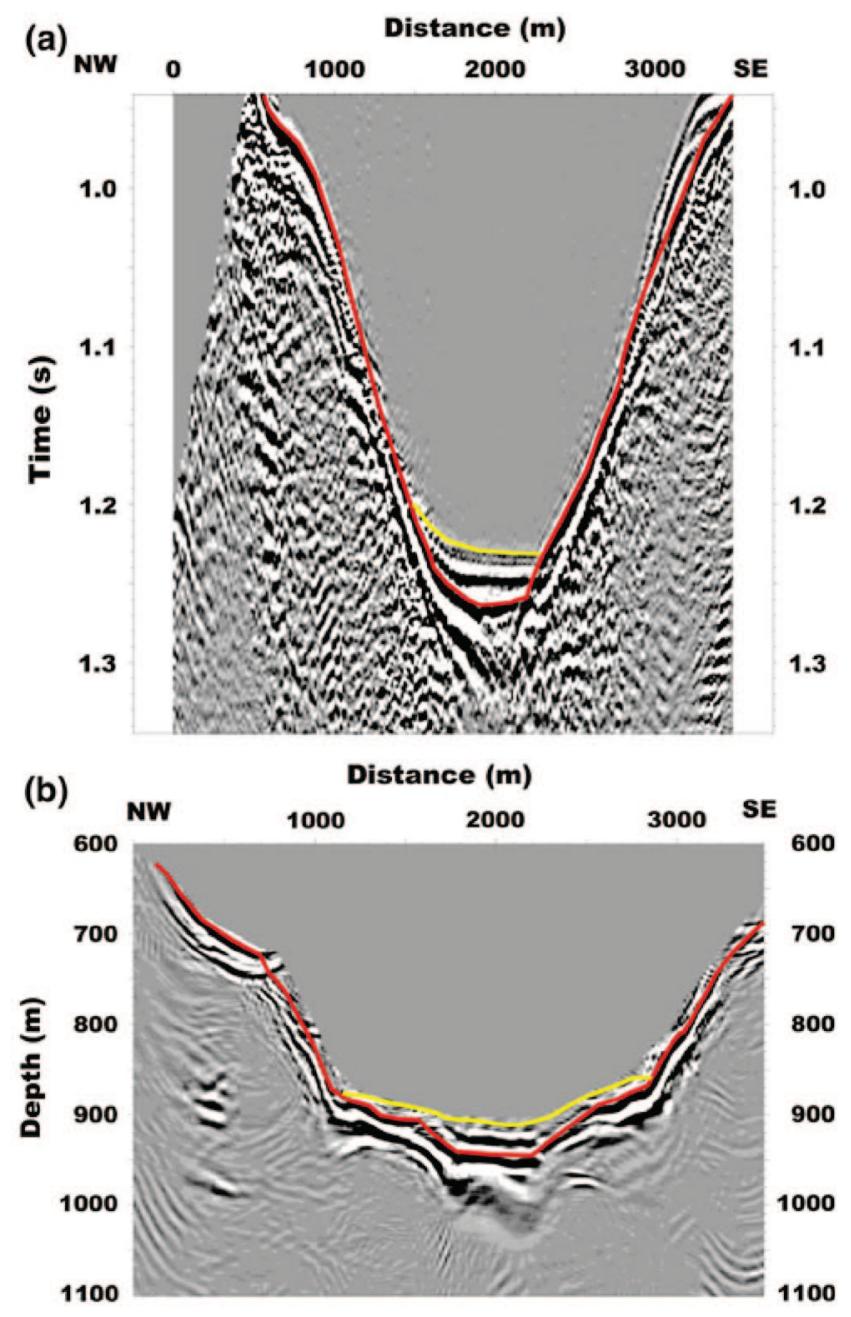

Figure 14. a) MSV-07-05 unmigrated CMP stacked time section with interpretations. The yellow line is the interpreted top of sediment and the red line is the top of the basement. The time section indicates 40 ms TWTT of sediment. b) MSV-07-05 depth migrated CMP stacked section with interpretations. The depth section indicates sediment up to $30 \mathrm{~m}$ thick.

$50 \mathrm{~m}$ of low amplitude sediment lie above the high amplitude granitic basement. The low-amplitude reflectors overlying the interpreted bedrock reflector indicate that the last glacial advance eroded previously deposited sediment in the MSV. The synthetic shot record of a thin pelagic sediment deposited directly above a granitic basement correlates well with these MSV shot records.

MSV-07-03, MSV-07-04, and MSV-07-06 show the possibility of imaging pre-Holocene sediment in the MSV. At the southern end of MSV-07-03 and the northern end of MSV-07-04, a high-amplitude reflector is observed below the interpreted granite reflection (Figs. 12b, 13b, respectively). A high-amplitude reflector (Figure 15b) is present below the interpreted granite reflector at the western end of MSV-07-06 and terminates to the east before it intersects lines MSV-07-07 and MSV-07-04. We expect no reflections below the 


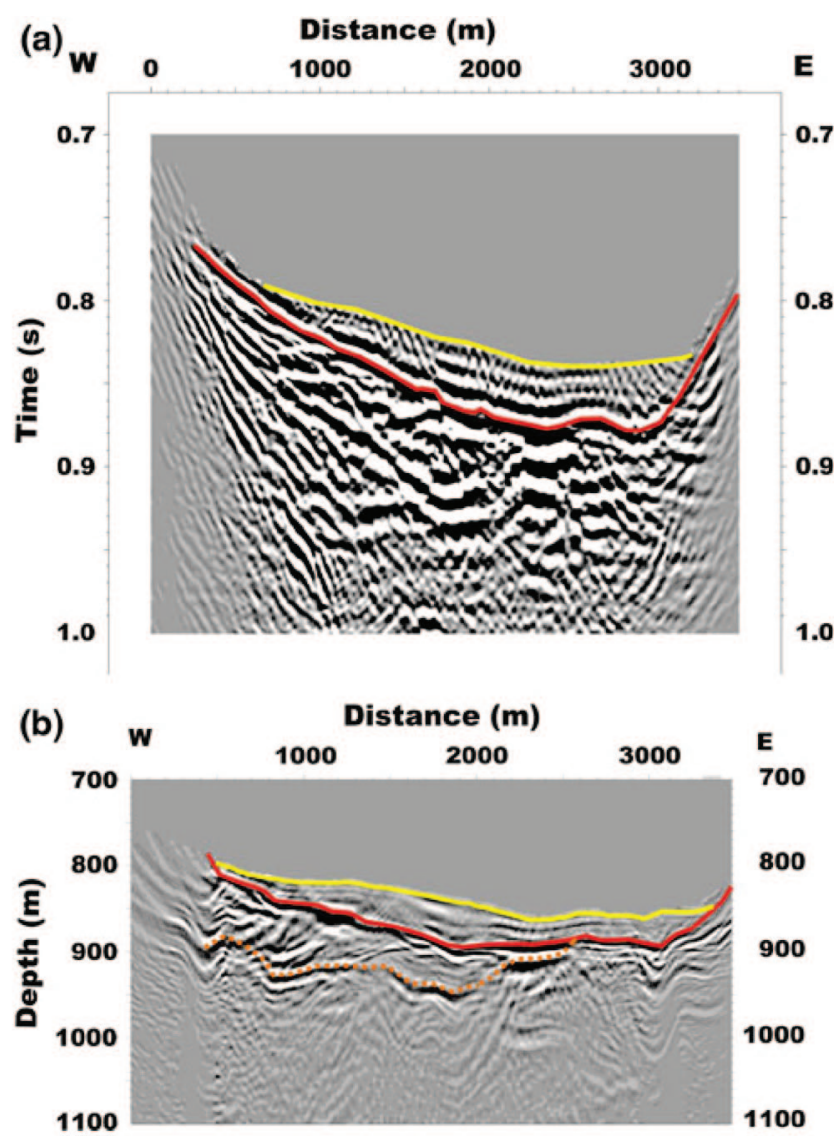

Figure 15. a) MSV-07-06 unmigrated CMP stacked time section with interpretations. The yellow line is the interpreted top of sediment and the red line is the top of the basement. The time section shows $50 \mathrm{~ms}$ TWTT of sediment. b) MSV-07-06 depth migrated CMP stacked section with interpretations. The depth section indicates a maximum sediment thickness of $40 \mathrm{~m}$. The dashed orange line is an alternative interpretation of the basement reflector.

granite reflection; hence these reflections could represent the actual top of the granite basement. If the top of the granite is moved to the lower reflector, then wedges of unknown sediment beneath the Holocene sediment and overlying the Late Ordovician granite might exist in the MSV under this alternative interpretation. This possible seismic unit could correspond to the gently folded rock that was imaged by Domack et al. (1999) and could represent glacially deposited diamictite or un-eroded Pleistocene to late Neogene aged sediment. This seismic unit is located at bathymetric highs within the MSV, along the valley walls, and in the case of MSV-07-06 at the inner side of the bend in the MSV. These locations might represent zones where interglacial sediment could have survived glacial erosion. The Mackay Glacier overriding and consequently compacting the sediment could have caused a high-amplitude seismic response for these sediments.

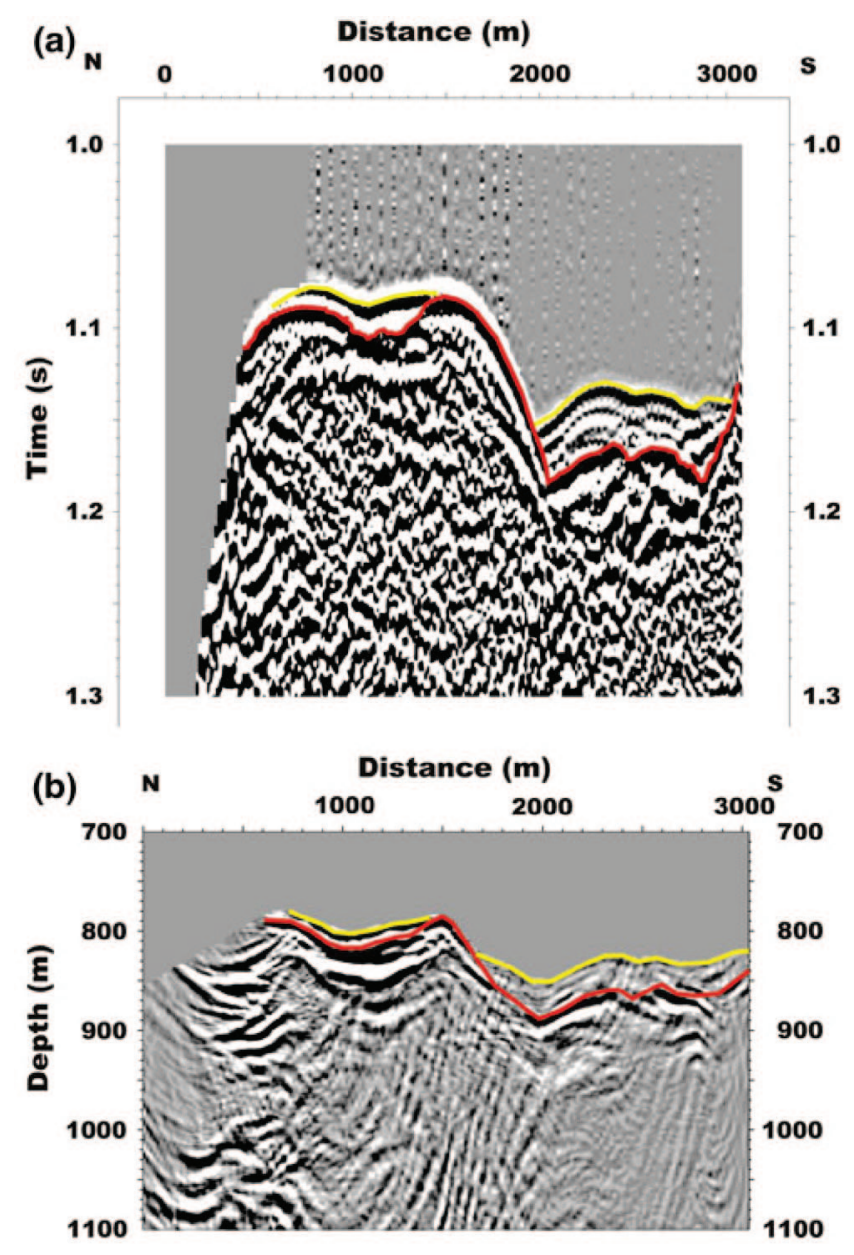

Figure 16. a) MSV-07-07 unmigrated CMP stacked time section with interpretations. The yellow line is the interpreted top of sediment and the red line is the top of the basement. The time section shows 45 ms TWTT of sediment. b) MSV-07-07 depth migrated CMP stacked section with interpretations. The depth section indicates sediment thickness of up to $35 \mathrm{~m}$.

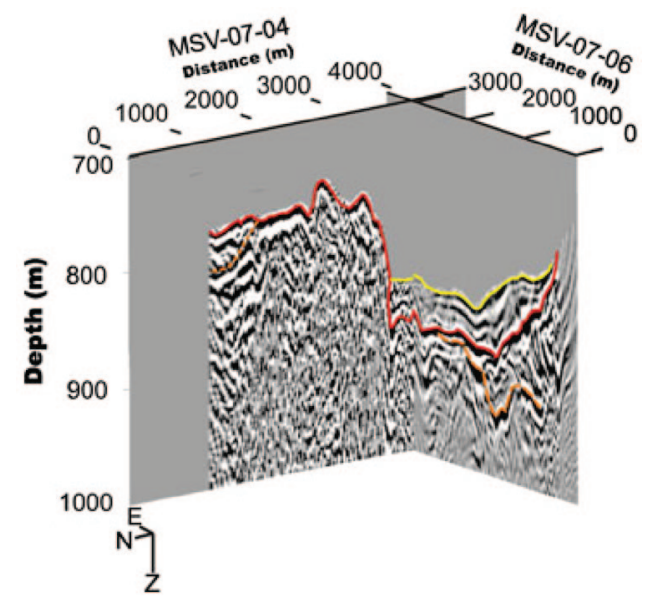

Figure 17. Fence diagram of MSV-07-04 and MSV-07-06 depthmigrated CMP stacked sections with interpretations. The yellow line indicates the interpreted top of sediment and the red line indicates the top of the basement. The dashed orange line is an alternate interpretation for the top of basement. 
The structure of the MSV derived from the MSV-07 survey corresponds well to the swath bathymetry collected by the NBP 94-01 and NBP 95-01 cruises. The fault that possibly drove the structure of the MSV discussed by Hamilton et al. $(1998,2001)$ was not crossed by the MSV-07 survey and therefore was not imaged. The thickest pelagic sediment occurs in the bathymetric lows within the MSV (Figure 17). Future drilling of these sediments could provide a detailed Holocene climate record.

\section{Conclusions}

The MSV-07 survey, despite using a relatively lowfrequency seismic source to conduct a relatively highresolution survey on a sea-ice platform, achieved an estimated vertical resolution of $6.3 \mathrm{~m}$ and imaged the pelagic sediment in the MSV. The true-GI- and harmonicsource modes had similar signatures which allowed the data from the two source modes to be processed and interpreted together. Unique problems inherent in oversea-ice reflection surveys had to be overcome before an interpretation was possible, including the correction of air-gun timing problems and the removal of the ice flexural mode. A synthetic shot record proved useful to validate our interpretation of a thin veneer of sediments overlying a granite basement. Final stacked sections indicate up to $65 \mathrm{~ms}$ TWTT of pelagic sediment within the MSV while the depth-migrated sections indicate that sediment thicknesses of up to $50 \mathrm{~m}$ are present. Highamplitude reflections that underlie the pelagic sediment are probably from the granite basement. However, some underlying glacially deposited diamictite or non-eroded late Neogene aged sediment could be present and responsible for some high-amplitude reflections that are present in lines MSV-07-03, MSV-07-04 and MSV-07-06.

Acknowledgments - The National Science Foundation funded the MSV survey through grant OPP-0342484. We thank Webster's Drilling and Exploration LTD for drilling shot holes, UNAVCO for providing GPS coordinates of shot locations, and the entire MSV survey crew. We thank Andrew McKee and Raytheon Polar services for logistical support. David Reichhardt, Curtis Link and two anonymous reviewers made important corrections to this manuscript. The seismic data were processed using Landmark Graphics ProMAX ${ }^{\circledR}$. Seismic interpretations were done in Kingdom Suite ${ }^{\circledR}$.

\section{References}

Barr FJ, Nyland DL, Sitton GA (1993) Attenuation of flexural ice waves and random noise using both geophones and hydrophones. Soc Explor Geophys Expand Abs 558-561
Barton C, Beresford-Smith G, Rango R (1986) Flexural waves on Arctic data: application of new techniques for S/N enhancement. Soc Explor Geophys Expand Abs 458-461

Beresford-Smith G, Rango RN (1988) Dispersive noise removal in the $t-x$ space: application to Arctic data. Geophys 53:346-358

Betterly SJ, Speece MA, Levy RH, Harwood DM, Henrys SA (2007) A novel over-sea-ice seismic reflection survey in McMurdo Sound, Antarctica. Terra Antartica 14(2):97-106

Burgess CJ, Palmer AJ, Anderson JM (1981) The geology of the Fry Glacier area, South Victoria Land, Antarctica, with particular reference to the Taylor group. NZ J Geol Geophys 24:373-388

Cape Roberts Science Team (1998) Initial Report from CRP-1, Cape Roberts Project, Antarctica. Terra Antartica 5:1-187

Cape Roberts Science Team (1999) Studies from the Cape Roberts Project, Ross Sea, Antarctica, Initial Report on CRP2/2A. Terra Antartica 6(245):1-173

Cape Roberts Science Team (2000) Studies from the Cape Roberts Project, Ross Sea, Antarctica, Initial Report on CRP-3. Terra Antartica 7:1-209

Clark SP Jr, Daly RA, Manger GE (eds) (1966) Handbook of physical constants. Revised edition, Memoir 97, Geological Society of America, New York

Conway H, Hall BL, Denton GH, Gades AM, Waddington ED (1999) Past and future grounding- line retreat of the West Antarctic Ice Sheet. Sci 286:280-283

Curren MG (1995) Descriptions of sediment recovered by the R/V Nathaniel B. Palmer, United States Antarctic Program Cruise 01, 1995. Antarctic Marine Geology Research Facility Florida State University Tallahassee, FL

Davy BW, Alder G (1989) Seismic reflection surveys. In: Barrett PJ (ed) Antarctic Cenozoic history from the CIROS-1 drillhole, McMurdo Sound. NZ Dep of Ind Res, pp 15-21

Del Molino G, Rovetta D, Mazzucchelli P, Sandroni S, Rizzo F, Andreoletti C (2008) Seismic exploration on ice: the flexural wave noise challenge. Soc Explor Geophys Expand Abs 27:2571-2575

Domack EW, Jacobson EK, Shipp S, Anderson JB (1999) Late Pleistocene-Holocene retreat of the West Antarctic Ice-Sheet system in the Ross Sea. Part 2. Sedimentologic and stratigraphic signature. Geol Soc Am Bull 111(10):1517-1536

Elliott CE (2006) Physical rock weathering along the Victoria Land Coast, Antarctica. Dissertation, University of Canterbury pp 123

Ewing M, Crary AP (1934) Propagation of elastic waves in ice, Part II. Physics 5:181-184

Gunn BM, Warren G (1962) Geology of Victoria Land between the Mawson and Mulock glaciers, Antarctica. NZ Geol Surv Bull 71:1-157

Hall BL, Denton GH (1999) New relative sea-level curves for the southern Scott Coast, Antarctica: evidence for Holocene deglaciation of the western Ross Sea. J Quater Sci 14(7):641-650

Hambrey MJ, Barrett PJ (1993) Cenozoic sedimentary and climatic record of the Ross Sea region of Antarctica. In: JP Kennett, DA Warnke (eds) The antarctic paleoenvironment: a perspective on global change. Part 2. Antarctic Res Series, Am Geophys Union,Washington, DC 60:91-124

Hamilton RJ, Sorlien CC, Luyendyk BP, Henrys SA (1998) Tectonic regimes and structural trends off Cape Roberts, Antarctica. Terra Antarct 5(3):261-272 
Hamilton RJ, Luyendyk BP, Sorlien CC (2001) Cenozoic tectonics of the Cape Roberts Rift Basin and Transantarctic Mountains Front, Southwestern Ross Sea, Antarctica. Tectonics 20(3):325-342

Horgan H, Bannister S (2004) Explosive source seismic experiments from a sea-ice platform, McMurdo Sound, 2003. Inst Geol Nucl Sci Sci Rep 15:1-27

Jensen SL, Janik T, Thybo H, Grad M, Gaczynski E, Guterch A, Keller GR, Miller KC (1999) Seismic structure of the Palaeozoic Platform along POLONAISE ‘97 profile P1 in northwestern Poland. Tectonophys 314(1-3):123-143

Kuzmin MI, Karabanov EB, Prokopenko AA, Gelety VF, Antipin VS, Williams DF, Gvozdkov AN (2000) Sedimentation processes and new age constraints on rifting stages in Lake Baikal: results of deep water drilling. Int J Earth Sci (Geologische Rundsch) 89(2):183-192

Lansley RM, Eilert PL, Nyland DL (1984) Surface sources on floating ice: the flexural ice wave. Soc Explor Geophys Expand Abs 3:828-831

Leventer A, Dunbar RB, DeMaster DJ (1993) Diatom evidence for late Holocene climatic events in Granite Harbour, Antarctica. Am Geophys Union Paleoceanogr 8(3):373-386

Lewis EL (1973) Sea ice and sound. Proceedings from National Convention. Canadian Soc Explor Geophys 164-169

Licht KJ, Jennings AE, Andrews JT, Williams KM (1996) Chronology of late Wisconsin ice retreat from the western Ross Sea, Antarctica. Geology 24(3):223-226

McConnell JR, Potts MJ, Schleicher KL, Wason CB (1986) Dispersive noise attenuation. Soc Explor Geophys Expand Abs 5:455-458

McGinnis LD (ed) (1981) Dry Valley Drilling Project: Antarctic Research Series. Am Geophys Union, Washington, DC 33:465

Nielsen C, Thybo H (2009) Lower crustal intrusions beneath the southern Baikal rift zone; Evidence from full-waveform modelling of wide-angle seismic data. Tectonphys 470(3-4):298-318. doi:10.1016/j.tecto.2009.01.023

Pocknall DT, Chinn TJ, Sykes R, Skinner DNB (1994) Geology of the Convoy Range area, southern Victoria Land, Antarctica. Lower Hutt, NZ, Inst of Geol and Nucl Sci

Powell R (2001) MacKay Sea Valley (MSV): Holocene high-frequency climate variations. In: Harwood DM, Lacy L, Levy RH (eds) Future antarctic margin drilling: developing a science program plan for McMurdo Sound: ANDRILL contribution 1, University of Nebraska-Lincoln. Lincoln, Nebraska, pp 88-95

Powell RD, Hambrey MJ, Krissek LA (1998) Quaternary and Miocene glacial and climatic history of the Cape Roberts drillsite region, Antarctica. Terra Antartica 5(3):341-351

Proubasta D (1985) Ice Saw - an incisive solution to seismic noise. The Leading Edge 4:18-23

Rebesco M, Camerlenghi A, De Santis L, Domack E, Kirby M (1998) Seismic stratigraphy of Palmer Deep: a faultbounded late quateranary sediment trap on the inner continential shelf, Antarctica Pennisula Pacific margin. Mar Geol 151:89-110

Sercel (2006) Marine sources. Sercel Inc

Shei S, Ward RW, Veith KF (1983) Flexural waves in floating ice. Soc Explor Geophys Expand Abs 2:258-261

Shipp S, Domack E, Anderson J (1999) Late Pleistocene-Holocene retreat of the West Antarctic Ice Sheet System in the Ross Sea. Part 1. Geophysical results. Geol Soc Am Bull 111(10):1486-1516

Speece MA, Levy RH, Harwood DM, Pekar SF, Powell RD (2009) New seismic methods to support sea-ice platform drilling. Sci Drill 7:40-43. doi:10.2204/iodp.sd.7.06.2009

Sugden D, Denton G (2004) Cenozoic landscape evolution of the Convoy Range to Mackay Glacier area, Transantarctic Mountains: Onshore to offshore synthesis. Geol Soc Am Bull 116(7/8):840-857. doi:10.1130/B25356.1

Sunwall D, Speece M, Pekar S (2010) Latest advances in oversea-ice seismic reflection surveys: offshore New Harbor, Antarctica. Soc of Explor Geophys Int Expo and Eightieth Annual Meet 2010 Tech Program, Expand Abs 36-40

Timco GW, Frederking RMW (1996) A review of sea ice density. Cold Reg Sci Technol 24:1-6 